\title{
PENGARUH ASAL POPULASI DAN POHON INDUK TERHADAP PERTUMBUHAN BIBIT MERANTI TEMBAGA (Shorea leprosula Miq.) SEBAGAI MATERI UNTUK PERBANYAKAN KLONAL
}

(The effect of population sources and parent trees on the growth of Shorea lerprosula Miq. seedlings for clonal propagation material)

\author{
$\mathrm{Oleh} / \mathrm{By}$ : \\ Mashudi $^{1)}$, Sugeng Pudjiono', ${ }^{1)}$ Rayan $^{2)}$ dan Maman Sulaeman ${ }^{3)}$ \\ ${ }^{1)}$ Peneliti Balai Besar Penelitian Biteknologi dan Pemuliaan Tanaman Hutan, Yogyakarta. \\ ${ }^{2)}$ Balai Besar Penelitian Dipterokarpa, Samarinda \\ ${ }^{3)}$ Peneliti Balai Besar Penelitian Biteknologi dan Pemuliaan Tanaman Hutan, Yogyakarta.
}

\begin{abstract}
The aim of this experiment was to identify the effects of population sources and parent trees on the growth of Shorea lerprosula seedlings for clonal propagation material. This experiment was arranged in completely randomized design with factorial setting. The research used 2 factors, i.e. population sources (Kenangan, East Kalimantan; Bukit Baka, Central Kalimantan and Gunung Bunga, West Kalimantan) and parents trees (19 parent trees from East Kalimantan, 4 parent trees from Central Kalimantan and 19 parent trees from West Kalimantan). In this experiment, parent trees factor was nested in the population sources. The result showed that population sources and parent trees were significantly affected the parameters measured, i.e. height, stem diameter and branching number. Kenangan population produced the best seedlings in term of height $(132.3 \mathrm{~cm})$, stem diameter $(10.6 \mathrm{~mm})$ and branching number (7.2). The best ten of parent trees for seedling height were parent trees number $7(173.3 \mathrm{~cm}), 3(166.1 \mathrm{~cm}), 4(165.8 \mathrm{~cm}), 6(160.8 \mathrm{~cm}), 18(150.0 \mathrm{~cm}), 27(142.1$ $\mathrm{cm}), 10(141.6 \mathrm{~cm}), 12(140.5 \mathrm{~cm}), 1(137.7 \mathrm{~cm})$ and $13(133.4 \mathrm{~cm})$. The best ten of parent trees for stem diameter were parent trees number $7(13.63 \mathrm{~mm}), 4(13.00 \mathrm{~mm}), 6(12.93 \mathrm{~mm}), 18(12.42 \mathrm{~mm}), 3$ $(12.35 \mathrm{~mm}), 10(11.11 \mathrm{~mm}), 17(11.03 \mathrm{~mm}), 15(10.96 \mathrm{~mm}), 19(10.78 \mathrm{~mm})$ and $1(10.63 \mathrm{~mm})$ while those for branching number were parent trees number 3 (8.7), 16 (8.5), 12 (8.1), 6 (8.0), 9 (7.9), 19 (7.5), 2 (7.4), 1 (7.3), 17 (7.3) and 11 (7.3).
\end{abstract}

Key Words : Shorea leprosula, population sources, parent trees, growth variation.

\begin{abstract}
ABSTRAK
Penelitan ini bertujuan untuk mengetahui pengaruh asal populasi dan pohon induk terhadap variasi pertumbuhan bibit meranti tembaga ( $S$. leprosula) sebagai materi untuk perbanyakan klonal. Rancangan percobaan yang digunakan adalah Rancangan Acak Lengkap (RAL) yang disusun secara faktorial dengan 2 faktor, yaitu asal populasi (Kenangan, Kalimantan Timur; Bukit Baka, Kalimantan Tengah dan Gunung Bunga, Kalimantan Barat) dan pohon induk (19 pohon induk dari Kaltim, 4 pohon induk dari Kalteng dan 19 pohon induk dari Kalbar). Dalam penelitian ini faktor pohon induk bersarang (nested) dalam faktor asal populasi. Hasil penelitian menunjukkan bahwa perlakuan asal populasi dan pohon induk berpengaruh sangat signifikan terhadap parameter yang diamati, yaitu tinggi, diameter batang dan jumlah percabangan. Populasi Kenangan menghasilkan bibit dengan tinggi, diameter batang dan jumlah percabangan terbesar yaitu masing-masing 132,3 cm;10,6 mm dan 7,2 buah. Sepuluh pohon induk terbaik dalam karakter tinggi bibit adalah pohon induk nomor 7, 3, 4, 6, 18, 27, 10, 12, 1 dan 13 berturut-turut sebesar 173,3 cm;166,1 cm; 165,8 cm; 160,8 cm; 150,0 cm; $142,1 \mathrm{~cm} ; 141,6 \mathrm{~cm} ; 140,5 \mathrm{~cm}, 137,7 \mathrm{~cm}$ dan $133,4 \mathrm{~cm}$. Sepuluh pohon induk terbaik dalam karakter
\end{abstract}


diameter batang adalah pohon induk nomor 7, 4, 6, 18, 3, 10, 17, 15, 19 dan 1 berturut-turut sebesar $13,63 \mathrm{~mm} ; 13,00 \mathrm{~mm} ; 12,93 \mathrm{~mm} ; 12,42 \mathrm{~mm} ; 12,35 \mathrm{~mm} ; 11,11 \mathrm{~mm} ; 11,03 \mathrm{~mm} ; 10,96 \mathrm{~mm} ; 10,78 \mathrm{~mm}$ dan $10,63 \mathrm{~mm}$. Sepuluh pohon induk terbanyak dalam karakter jumlah percabangan adalah pohon induk nomor 3, 16, 12, 6, 9, 19, 2, 1, 17 dan 11 berturut-turut sebanyak 8,7 cabang; 8,5 cabang; 8,1 cabang; 8,0 cabang; 7,9 cabang; 7,5 cabang; 7,4 cabang; 7,3 cabang; 7,3 cabang dan 7,3 cabang.

\section{Kata Kunci : Shorea leprosula, asal populasi, pohon induk, variasi pertumbuhan..}

\section{PENDAHULUAN}

Produksi kayu dari hutan alam di luar Jawa cenderung menurun dari tahun ke tahun, sementara kebutuhan kayu untuk bahan baku industri terjadi sebaliknya. Semakin menurunnya kemampuan produksi hutan alam secara lestari untuk menyediakan bahan baku industri, memberikan konsekuensi pembangunan hutan tanaman dengan produktivitas tinggi sebagai salah satu alternatif pilihan yang dapat dilakukan untuk mengatasi permasalahan tersebut. Terkait dengan permasalahan tersebut maka keberadaan benih/ bibit unggul untuk mendukung pembangunan hutan tanaman dengan produktivitas tinggi sangat diperlukan.

Meranti tembaga (Shorea leprosula Miq.) merupakan salah satu jenis dipterokarpa yang mempunyai potensi bagus untuk pengembangan hutan tanaman di luar Jawa. Di Indonesia, jenis ini tumbuh secara alami di Sumatera dan Kalimantan (Rudjiman dan Adriyanti, 2002) dan merupakan jenis meranti yang mempunyai pertumbuhan paling cepat sampai umur 20 tahun dibandingkan jenis meranti lainnya (IFSP, 2002). Dalam program teknik silvikultur intensif (SILIN) jenis ini dijadikan sebagai spesies standar, karena sebaran yang luas sehingga mudah didapat di seluruh Pulau Sumatera dan Kalimantan, mudah ditanam, harga cukup tinggi, dan pertumbuhannya relatif cepat. Menurut Appanah dan Weinland (1993), diameter batang S. leprosula umur 40 tahun di Kepong, Malaysia dapat mencapai 73,6 $\mathrm{cm}$ atau dengan riap rerata sebesar 1,82 cm. Kayunya sangat baik untuk joinery furniture, panel, lantai, langit-langit dan juga untuk kayu lapis sehingga sangat diminati oleh pengusaha kayu. Eksploitasi yang berlebihan menyebabkan penurunan populasi jenis ini sangat cepat sehingga menurut daftar IUCN tergolong langka (IFSP, 2002). Pengembangan hutan tanaman dengan produktivitas tinggi sangat diharapkan dari jenis ini. Untuk mencapai tujuan tersebut, penyediaan bibit berkualitas unggul sangat diperlukan keberadaannya. Upaya kegiatan pemuliaan terhadap jenis ini telah dilakukan, diantaranya pemilihan pohon plus di sebaran alami, pembangunan bank klon, pembangunan uji keturunan serta studi keragaman genetik melalui biologi molekuler (Soeseno, 2001; Siregar, 2001; Rimbawanto dan Isoda, 2001; Sudarmonowati dkk., 2001; Prihatini dkk., 2001; Yasman dan Natadiwirya, 2001).

Perbanyakan secara generatif jenis ini dipandang masih menemui beberapa kendala karena sifat bijinya yang tidak dapat disimpan dalam jangka panjang (rekalsitran) (Sasaki, 1980) dan musim berbunganya yang tidak berlangsung setiap tahun (Ashton, dkk., 1998). 
Krishnapillay \& Tompsett (1998) memperkirakan frekuensi pembungaan pada $S$. leprosula berkisar antara tiga sampai empat tahun sekali. Selain itu, dari aspek perbanyakan vegetatif makro, jenis ini sulit diperbanyak dari materi pohon induk yang tua. Bertolak dari hal tersebut, maka perbanyakan secara vegetatif melalui teknik stek pucuk dapat dijadikan solusi alternatif untuk memenuhi kebutuhan bibit jenis $S$. leprosula. Berdasarkan hasil penelitian Danu dkk. (2010), persen berakar stek pucuk dari materi tanaman umur muda ( \pm 2 tahun) dengan sistem KOFFCO relatif tinggi yaitu sebesar 88,33\%. Aminah dkk. (1997) menyampaikan bahwa persen berakar stek batang $S$. leprosula cukup tinggi yaitu berkisar antara 55 - 82\%. Berdasarkan data-data tersebut perbanyakan vegetatif $S$. leprosula dapat menjamin keberhasilan jika dilaksanakan.

Materi genetik dari hutan alam diambil untuk mendapatkan bibit $S$. leprosula berkualitas tinggi. Langkah awal yang dilakukan adalah pengambilan benih dari pohon-pohon induk terpilih yang secara fenotipik unggul, sehingga anakan yang dihasilkan diharapkan bagus. Benih dari pohon-pohon induk terpilih selanjutnya disemaikan dan kemudian diseleksi. Seleksi dilakukan dalam dua tahap, yaitu seleksi pertumbuhan untuk tahap pertama dan seleksi heterosigositas untuk tahap kedua. Setelah seleksi tahap kedua, bibit terseleksi selanjutnya diperbanyak secara vegetatif dengan teknik stek pucuk dan digunakan sebagai materi untuk uji klon. Terkait dengan kegiatan seleksi tahap pertama maka penelitian ini dilakukan dengan tujuan untuk mengetahui pengaruh asal populasi dan pohon induk terhadap variasi pertumbuhan bibit S. leprosula sebagai materi untuk perbanyakan klonal.

\section{BAHAN DAN METODE}

\section{A. Lokasi dan Waktu}

Penelitian dilaksanakan di persemaian Balai Besar Penelitian Bioteknologi dan Pemuliaan Tanaman Hutan, Yogyakarta. Secara geografis lokasi penelitian berada pada $7^{\circ} 40^{\prime} 35^{\prime \prime}$ LS dan $110^{\circ} 23^{\prime} 23^{\prime \prime} \mathrm{BT}, 287 \mathrm{~m}$ dpl, curah hujan rata-rata $1.878 \mathrm{~mm} /$ tahun, suhu rata-rata $27^{\circ} \mathrm{C}$ dan kelembaban relatif $73 \%$. Kegiatan penelitian dilaksanakan mulai Maret 2010 sampai dengan Agustus 2011.

\section{B. Bahan dan Alat}

Bahan yang dipergunakan adalah bibit meranti tembaga umur 18 bulan dari 3 populasi, yaitu Kenangan (Kalimantan Timur), Bukit Baka, Katingan (Kalimantan Tengah) dan Gunung Bunga, Ketapang (Kalimantan Barat). Bahan-bahan yang lain adalah polibag ukuran $12 \times 10 \mathrm{~cm}$, dan ukuran $25 \times 25 \mathrm{~cm}$, top soil, kompos, sarlon, fungisida Score dan insektisida Curachron, sedangkan alat yang dipergunakan antara lain adalah cangkul, sekop, sprayer, kaliper, selang, penggaris, kertas label, kamera dan alat tulis menulis.

\section{Pelaksanaan Penelitian}

Tahapan penelitian yang dilakukan meliputi:

\section{Pembibitan}

Kegiatan pembibitan diawali dengan penyiapan media tanam berupa campuran top soil + kompos (4:1) yang dimasukkan ke dalam polibag ukuran $12 \times 10 \mathrm{~cm}$. Polibag yang telah diisi media tanam selanjutnya ditempatkan di 
dalam bedeng persemaian yang di bagian atasnya telah dipasang sarlon dengan kerapatan 65\%. Kegiatan selanjutnya adalah penanaman benih $S$. leprosula, setiap polibag ditanam satu benih dan untuk masing-masing pohon induk ditanam 200 benih.

\section{Pemeliharaan bibit}

Kegiatan pemeliharaan yang dilakukan adalah penyiraman, penyiangan dan pengendalian hama/penyakit. Sampai umur 2 bulan setelah penaburan (penanaman) kegiatan penyiraman dilakukan 2 kali/hari, yaitu pada pagi dan sore. Selepas 2 bulan penyiraman dilakukan 1 kali/ hari, yaitu pada pagi hari. Kegiatan penyiangan dilakukan secara rutin (sebulan sekali). Pengendalian hama dan penyakit dilakukan secara rutin (2 minggu sekali) dengan menggunakan insektisida Curachron dan fungisida Score.

\section{Seleksi bibit}

Seleksi bibit dilakukan untuk memilih pertumbuhan 10 bibit terbaik per pohon induk. Seleksi dilakukan pada saat bibit berumur 8 bulan setelah penanaman (penaburan). Bibit-bibit yang terseleksi selanjutnya dipindah dalam polibag ukuran $25 \times 25 \mathrm{~cm}$ agar pertumbuhannya tetap optimal.

4. Pengambilan data

Pengambilan data dilakukan pada saat bibit berumur 18 bulan. Karakter yang didata meliputi: tinggi bibit, diameter batang dan jumlah percabangan.

\section{Rancangan Penelitian}

Penelitian dilaksanakan dengan menggunakan Rancangan Acak Lengkap (RAL) yang terdiri dari 2 faktor, yaitu asal populasi (A) dan pohon induk (B). Dalam penelitian ini faktor B bersarang (nested) dalam faktor A. Faktor A terdiri dari 3 asal populasi, yaitu: $\mathrm{A} 1=$ asal populasi Kenangan, Kalimantan Timur; A2 = asal populasi Bukit Baka, Kalimantan Tengah; dan $\mathrm{A} 3=$ asal populasi Gunung Bunga, Kalimantan Barat. Faktor B terdiri dari 43 pohon induk, yaitu 19 pohon induk asal dari Kalimantan Timur, 19 pohon induk asal dari Kalimantan Barat dan 4 pohon induk asal dari Kalimantan

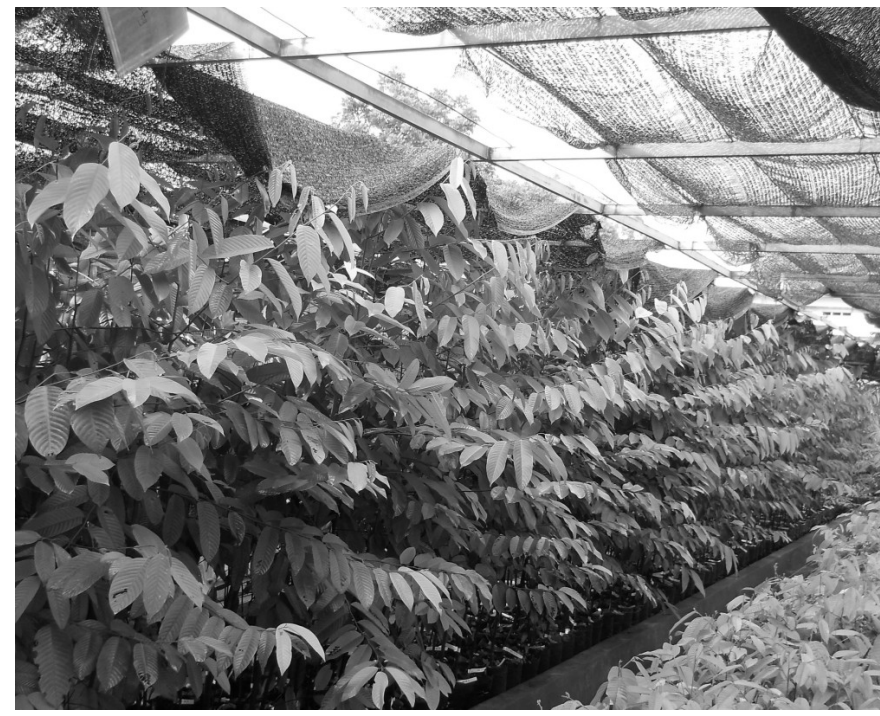

Gambar (Figure) 1. Bibit S. leprosula terseleksi umur 18 bulan di persemaian (S. leprosula seedling selected on 18 month old in nursery) 
Tengah. Untuk masing-masing pohon induk digunakan 2 bibit dengan ulangan sebanyak 5 kali, sehingga jumlah bibit yang dipergunakan dalam penelitian ini sebanyak $43 \times 2 \times 5=430$ individu.

\section{E. Analisis Data}

Data hasil pengamatan dan pengukuran dianalisis menurut prosedur Rancangan Acak Lengkap. Untuk mengetahui perlakuan yang berpengaruh nyata dilakukan analisis sidik ragam (analisis varians) dengan model sebagai berikut (Steel dan Torrie, 1981):

$$
\mathrm{Y}_{\mathrm{ijk}}=\mu+\mathrm{R}_{\mathrm{i}}+\mathrm{A}_{\mathrm{j}}+\mathrm{B}_{\mathrm{k}}\left(\mathrm{A}_{\mathrm{j}}\right)+\mathrm{R}_{\mathrm{i}}^{*} \mathrm{~B}_{\mathrm{k}}\left(\mathrm{A}_{\mathrm{j}}\right)+\varepsilon_{\mathrm{ijk}}
$$

dengan :

$\mathrm{Y}_{\mathrm{ijk}}=$ rata-rata pengamatan pada ulangan ke-i, asal populasi ke-j, pohon induk ke-k; $\mu=$ rata-rata umum; $R_{i}=$ pengaruh ulangan ke-i; $A_{j}=$ pengaruh asal populasi ke- $\mathrm{j} ; \mathrm{B}_{\mathrm{k}}=$ pengaruh pohon induk ke-k; $\mathrm{R}_{\mathrm{i}}{ }^{*} \mathrm{~B}_{\mathrm{k}}\left(\mathrm{A}_{\mathrm{j}}\right)=$ pengaruh interaksi replikasi ke-i dan pohon induk ke-k yang bersarang dalam populasi ke-j; dan $\varepsilon_{\mathrm{ijk}}=$ galat
Apabila hasil analisis varians menunjukkan perbedaan yang signifikan, maka dilanjutkan dengan Uji Duncan Multiple Range Test (DMRT) untuk mengetahui perbedaan pengaruh masing-masing perlakuan.

\section{HASIL DAN PEMBAHASAN}

Berdasarkan hasil pengamatan dan pengukuran, diketahui bahwa tinggi, diameter batang dan jumlah percabangan bibit cukup bervariasi. Hasil perhitungan menunjukkan rata-rata tinggi bibit berkisar antara 39-173,3 cm, diameter batang berkisar antara 5,03-13,63 $\mathrm{mm}$ dan jumlah percabangan berkisar antara 2,5-8,7. Untuk mengetahui pengaruh perlakuan terhadap parameter yang diamati dilakukan analisis varians. Hasil analisis varians disajikan pada Tabel 1.

Tabel 1 menunjukkan bahwa perlakuan asal populasi (A) dan pohon induk (B) berpengaruh sangat nyata terhadap karakter tinggi bibit, diameter batang dan jumlah percabangan.

Tabel (Table) 1. Hasil analisis varians untuk tinggi, diameter batang dan jumlah percabangan bibit Shorea leprosula umur 18 bulan. (Variance analysis result on height, stem diameter and number of branches on 18 months Shorea leprosula seedling)

\begin{tabular}{|c|c|c|c|c|}
\hline \multirow[b]{2}{*}{$\begin{array}{c}\text { Sumber Variasi } \\
\text { (Source of variation) }\end{array}$} & \multirow{2}{*}{$\begin{array}{l}\text { Derajat } \\
\text { Bebas } \\
\text { (Degree of } \\
\text { freedom) }\end{array}$} & \multicolumn{3}{|c|}{$\begin{array}{c}\text { Kuadrat Tengah } \\
\text { (Mean square) }\end{array}$} \\
\hline & & $\begin{array}{l}\text { Tinggi Bibit } \\
\text { (Height) }\end{array}$ & $\begin{array}{c}\text { Diameter Batang } \\
\text { (Stem diameter) }\end{array}$ & $\begin{array}{c}\text { Jumlah } \\
\text { Percabangan } \\
\text { (Number of } \\
\text { branches) }\end{array}$ \\
\hline Replikasi (R) & 4 & $467,1762 \mathrm{~ns}$ & $2,8598 \mathrm{~ns}$ & $2,0929 \mathrm{~ns}$ \\
\hline Populasi (A) & 2 & $70908,4775 * *)$ & $363,2757 * *)$ & $304,0502 * *)$ \\
\hline Pohon Induk $\{\mathrm{B}(\mathrm{A})\}$ & 39 & $4739,3868 * *)$ & $21,2960 * *)$ & $8,4880 * *)$ \\
\hline Sisa & 374 & 543,4385 & 2,7473 & 3,0659 \\
\hline Total & 419 & & & \\
\hline
\end{tabular}

Keterangan (Remarks): $* *)=$ berbeda sangat nyata (significant); $\mathrm{ns}=$ tidak berbeda nyata (non significant) 


\section{A. Asal Populasi}

Hasil analisis varians (Tabel 1) menunjukkan bahwa perlakuan asal populasi berpengaruh sangat nyata terhadap tinggi, diameter batang dan jumlah percabangan bibit. Hal ini terjadi kemungkinan karena ketiga populasi berada pada sebaran areal yang saling berjauhan (Tabel 2), sehingga proses diferensiasi populasi berjalan sendiri-sendiri dan menyebabkan masing-masing populasi mengembangkan karakter dan ciri spesifik secara morfologis dan genetik yang berbeda dengan populasi lainnya (Hartati dkk., 2007). Hasil penelitian lain menunjukkan bahwa proporsi keragaman genetik dalam populasi jenis S. leprosula relatif besar (96\%) (Rimbawanto dan Suharyanto, 2005), sehingga nilai keragaman yang besar tersebut kemungkinan akan mendukung proses diferensiasi dalam populasi. Hasil penelitian tersebut juga didukung oleh hasil penelitian Cao dkk. (2006), bahwa proporsi keragaman genetik dalam populasi jenis $S$. leprosula di Indonesia sebesar 70,2\%.

Selanjutnya untuk mengetahui lebih detail perlakuan yang memberikan hasil berbeda nyata, maka dilakukan Uji Jarak Berganda Duncan (DMRT) sebagaimana disajikan pada Tabel 3.

Tabel 3 menunjukkan bahwa populasi Kaltim menghasilkan bibit dengan tinggi, diameter batang dan jumlah percabangan yang terbesar, disusul populasi Kalbar dan terakhir populasi Kalteng. Hal ini sejalan dengan hasil penelitian Na'iem dkk. (2005) di PT. ITCIKU, Kalimantan Timur bahwa untuk rata-rata tinggi dan diameter batang tanaman pada uji keturunan S. leprosula umur 2,5 tahun, populasi Kalimantan Timur lebih baik dari populasi Kalimantan

Tabel (Table) 2. Ketinggian tempat dan letak geografis dari 3 populasi sebaran alami S. leprosula (Altitudinal and geographical site on three natural distribution of $\mathrm{S}$. leprosula)

\begin{tabular}{|c|c|c|c|c|}
\hline \multirow{2}{*}{$\begin{array}{c}\text { No. } \\
\text { (Number) }\end{array}$} & \multirow{2}{*}{$\begin{array}{l}\text { Lokasi } \\
\text { (Location) }\end{array}$} & \multirow{2}{*}{$\begin{array}{c}\text { Ketinggian } \\
\text { Tempat (m dpl) } \\
\text { (Altitudinal) }\end{array}$} & \multicolumn{2}{|c|}{$\begin{array}{l}\text { Koordinat } \\
\text { (Coordinate) }\end{array}$} \\
\hline & & & Lintang Selatan & Bujur Timur \\
\hline 1. & Kenangan, Kalimantan Timur & $200-400$ & $\begin{array}{l}00^{\circ} 44^{\prime} 57,0^{\prime \prime}- \\
00^{\circ} 57^{\prime} 50,1^{\prime \prime}\end{array}$ & $\begin{array}{l}116^{\circ} 20^{\prime} 56,4^{\prime \prime}- \\
116^{\circ} 31 ' 53,3^{\prime \prime}\end{array}$ \\
\hline 2. & Bukit Baka, Kalimantan Tengah & $134-200$ & $\begin{array}{l}00^{\circ} 00^{\prime} 16,7^{\prime \prime}- \\
01^{\circ} 05^{\prime} 33,2^{\prime \prime}\end{array}$ & $\begin{array}{l}112^{\circ} 20^{\prime} 45,5^{\prime \prime}- \\
112^{\circ} 22 \text { ' } 10,1^{\prime \prime}\end{array}$ \\
\hline 3. & $\begin{array}{l}\text { Gunung Bunga-Beginci dan } \\
\text { Sungai Runtin, Kalimantan Barat }\end{array}$ & $77-180$ & $\begin{array}{l}01^{\circ} 07^{\prime} 22,99^{\prime \prime}- \\
01^{\circ} 30 ’ 39,3^{\prime \prime}\end{array}$ & $\begin{array}{l}110^{\circ} 42^{\prime} 28,1^{\prime \prime}- \\
111^{\circ} 07 ' 17,4 ”\end{array}$ \\
\hline
\end{tabular}

Tabel (Table) 3. Pengaruh asal populasi terhadap tinggi bibit, diameter batang dan jumlah percabangan bibit $S$. leprosula umur 18 bulan (Effect of population sources to seedlings height, stem diameter, dan number of branches on 18 months $\mathrm{S}$. leprosula seedling)

\begin{tabular}{lccc} 
Karakter & \multicolumn{3}{c}{ Asal Populasi (A) (Source of population (A)) } \\
\cline { 2 - 4 }$($ Character) & $\mathbf{A 1}$ & $\mathbf{A 2}$ & $\mathbf{A 3}$ \\
\hline Tinggi bibit**) & $132,3 \mathrm{a}$ & $75,7 \mathrm{c}$ & $106,7 \mathrm{~b}$ \\
\hline Diameter batang**) & $10,6 \mathrm{a}$ & $6,8 \mathrm{c}$ & $8,4 \mathrm{~b}$ \\
\hline Jumlah percabangan**) & $7,2 \mathrm{a}$ & $3,6 \mathrm{c}$ & $5,2 \mathrm{~b}$ \\
\hline
\end{tabular}

Keterangan (Remarks): $\left.{ }^{* *}\right)=$ nilai yang diikuti huruf yang sama tidak berbeda nyata pada taraf 0,01; A1 = Kaltim; A2 = Kalteng; dan A3 = Kalbar. 
Tengah. Rata-rata tinggi dan diameter batang tanaman dari populasi Kaltim sebesar 1,37 $\mathrm{m}$ dan $1,30 \mathrm{~cm}$, sedang populasi Kalteng sebesar 1,23 m dan $1,12 \mathrm{~cm}$. Hasil penelitian lain menunjukkan bahwa keragaman genetik populasi Gunung Bunga, Kalbar lebih tinggi $(0,2560)$ dibandingkan keragaman genetik populasi Bukit Baka, Kalteng $(0,2227)$ (Rimbawanto dan Suharyanto, 2005) dan berkorelasi positif terhadap tinggi, diameter batang dan jumlah percabangan dari bibit yang dihasilkan. Zobel dan Talbert (1984) menyatakan bahwa keragaman genetik yang tinggi bisa disebabkan oleh adanya perkawinan silang (outcrossing), polinasi yang terjadi dengan bantuan serangga dan juga luasnya distribusi $S$. leprosula (Rimbawanto dan Isoda, 2001), daur hidup yang panjang, kejadian-kejadian selama tahapan suksesi, belum adanya perlakuan dari manusia, serta perkawinan antar induk yang telah teridentifikasi dengan induk yang belum teridentifikasi (half-sib mating) (Lestyaningsih dkk., 2005).

Hasil penelitian yang berbeda disampaikan Soekotjo (2009) yang menyatakan bahwa populasi Bukit Baka, Kalteng menunjukkan pertumbuhan yang lebih baik dibandingan dengan populasi Gunung Bunga, Kalbar pada tanaman uji keturunan $S$. leprosula umur 4 tahun di PT. Sari Bumi Kusuma, Kalbar. Menurut uji tersebut rata-rata tinggi dan diameter batang tanaman dari populasi Bukit Baka masing-masing sebesar 5,29 $\mathrm{m}$ dan $6,47 \mathrm{~cm}$, sedangkan untuk populasi Gunung Bunga masing-masing sebesar 3,53 $\mathrm{m}$ dan $5,29 \mathrm{~cm}$. Hasil penelitian di PT. Sari Bumi Kusuma tersebut berlawanan dengan hasil penelitian ini, karena dalam penelitian ini populasi Gunung
Bunga lebih baik dari populasi Bukit Baka. Hal ini dimungkinkan terjadi karena materi genetik (buah) dari populasi Bukit Baka, Kalteng yang digunakan dalam penelitian ini berasal dari pohon-pohon hasil selfing atau kawin kerabat, karena musim buah yang tidak serempak saat pengambilan materi genetik, sehingga pertumbuhannya kurang bagus. Menurut Hodgson (1976), selfing pada tanaman E. grandis mengakibatkan penurunan produksi benih, pertumbuhan semai yang abnormal, pertumbuhan lambat dan bentuk batang keturunan yang jelek. Sementara itu, kawin antar saudara kandung (full-sibs) dan antar saudara tiri (half-sibs) juga mempunyai efek negatif pada jenis E. grandis (Wyk, 1981).

\section{B. Pohon Induk}

Hasil analisis varians (Tabel 1) menunjukkan bahwa perlakuan pohon induk berpengaruh sangat nyata terhadap tinggi, diameter batang dan jumlah percabangan bibit $S$. leprosula. Hal ini sejalan dengan hasil penelitian Rimbawanto dan Suharyanto (2005) dan Cao dkk. (2006) bahwa keragaman genetik dalam populasi $S$. leprosula cukup tinggi, ini mencerminkan bahwa variasi genetik dari individu-individu penyusun populasi cukup tinggi. Untuk lebih detail mengetahui perlakuan yang memberikan hasil berbeda nyata, maka dilakukan Uji Jarak Berganda Duncan (DMRT) sebagaimana disajikan pada Lampiran 1. Ranking 10 pohon induk tertinggi dalam karakter tinggi, diameter batang dan jumlah percabangan pada bibit secara rinci disajikan pada Tabel 4.

Tabel 4. menunjukkan bahwa rata-rata tinggi bibit 10 pohon induk terbaik mencapai $151,1 \mathrm{~cm}$ 
Tabel (Table) 4. Ranking 10 pohon induk tertinggi dalam karakter tinggi, diameter batang dan jumlah percabangan bibit $S$. leprosula umur 18 bulan (The 10 highest parent trees rank on height, diameter and number of branches on 18 months $\mathrm{S}$. leprosula seedling)

\begin{tabular}{|c|c|c|c|c|c|c|}
\hline \multirow[b]{2}{*}{$\underset{\text { (Number) }}{\text { No. }}$} & \multicolumn{2}{|c|}{$\begin{array}{c}\text { Tinggi Bibit } \\
\text { (Seedlings height) }\end{array}$} & \multicolumn{2}{|c|}{$\begin{array}{l}\text { Diameter Batang } \\
\text { Stem diameter }\end{array}$} & \multicolumn{2}{|c|}{$\begin{array}{l}\text { Jumlah Percabangan } \\
\text { Number of branches }\end{array}$} \\
\hline & $\begin{array}{c}\text { Pohon } \\
\text { Induk } \\
\text { (Parent trees) }\end{array}$ & $\begin{array}{c}\text { Rata-rata } \\
\text { Tinggi } \\
\text { (cm) } \\
\text { (Average of } \\
\text { height) }\end{array}$ & $\begin{array}{c}\text { Pohon } \\
\text { Induk } \\
\text { (Parent trees) }\end{array}$ & $\begin{array}{l}\text { Rata-rata } \\
\text { Diameter } \\
(\mathbf{m m}) \\
\text { (Average of } \\
\text { diameter) }\end{array}$ & $\begin{array}{c}\text { Pohon } \\
\text { Induk } \\
\text { (Parent trees) }\end{array}$ & $\begin{array}{c}\text { Rata-rata } \\
\text { Percabangan } \\
\text { (Average of } \\
\text { branches) }\end{array}$ \\
\hline 1. & 7 & $173,3 \mathrm{a}$ & 7 & $13,63 \mathrm{a}$ & 3 & $8,7 \mathrm{a}$ \\
\hline 2. & 3 & $166,1 \mathrm{ab}$ & 4 & $13,00 \mathrm{a}$ & 16 & $8,5 \mathrm{ab}$ \\
\hline 3. & 4 & $165,8 \mathrm{ab}$ & 6 & $12,93 \mathrm{a}$ & 12 & $8,1 \mathrm{abc}$ \\
\hline 4. & 6 & 160,8 abc & 18 & $12,42 \mathrm{ab}$ & 6 & 8,0 abc \\
\hline 5. & 18 & 150,0 bcd & 3 & $12,35 \mathrm{ab}$ & 9 & 7,9 abcd \\
\hline 6. & 27 & $142,1 \quad \mathrm{cde}$ & 10 & $11,11 \quad b c$ & 19 & 7,5 abcde \\
\hline 7. & 10 & $141,6 \quad \mathrm{cde}$ & 17 & $11,03 \mathrm{bc}$ & 2 & 7,4 abcde \\
\hline 8. & 12 & 140,5 & 15 & $10,96 \mathrm{bc}$ & 1 & 7,3 abcde \\
\hline 9. & 1 & 137,7 & 19 & 10,78 bcd & 17 & 7,3 abcde \\
\hline 10. & 13 & 133,4 & 1 & $10,63 \mathrm{cde}$ & 11 & 7,3 abcde \\
\hline & Jumlah & $1.511,3$ & Jumlah & 118,84 & Jumlah & 78 \\
\hline & Rata-rata & 151,1 & Rata-rata & 11,9 & Rata-rata & 7,8 \\
\hline
\end{tabular}

atau dengan riap sebesar $8,4 \mathrm{~cm} /$ bulan. Riap tersebut lebih besar jika dibandingkan dengan hasil penelitian Heriyanto dan Masano (1997), dengan bibit $S$. leprosula di persemaian dari perlakuan beberapa jenis media mempunyai riap tinggi berkisar antara 0,76 - 3,05 cm/bulan. Riap hasil penelitian ini juga lebih besar dari hasil penelitian Irwanto (2006), dengan bibit $S$. leprosula di tempat terbuka mempunyai riap tinggi $2,7 \mathrm{~cm} /$ bulan dan di dalam green house mempunyai riap tinggi sebesar $2,3 \mathrm{~cm} / \mathrm{bulan}$. Pertumbuhan tinggi tanaman dalam penelitian ini juga masih lebih baik bila dibandingkan dengan tanaman S. leprosula umur 1,5 tahun yang ditanam pada tempat terbuka, yaitu setinggi 1,2 m (Sagala, 1994). Hal ini dimungkinkan terjadi karena pada penelitian ini materi genetik yang digunakan dipilih dari pohon-pohon induk yang berfenotipe bagus sehingga anakan yang dihasilkan juga bagus, karena sifat induk yang bagus akan diwariskan kepada keturunannya. Apabila dibandingkan dengan jenis Shorea yang lain yaitu $S$. ovalis dengan perlakuan dosis pupuk NPK 15-15-15 sebanyak 0-1 g/bibit, riap pertumbuhan S. leprosula jauh lebih baik. Dalam penelitian Herdiana dkk. (2008) riap tinggi bibit S. ovalis berkisar antara $0,84-3,88 \mathrm{~cm} / \mathrm{bulan}$. Riap tinggi bibit $S$. leprosula juga lebih baik dari S. selanica. Hasil penelitian Kosasih dan Heryati (2006) menunjukkan riap tinggi bibit $S$. selanica dengan perlakuan beberapa jenis media berkisar antara 0,87 - 1,9 cm/bulan. Hal ini sejalan dengan tulisan IFSP (2002), bahwa S. leprosula merupakan jenis Shorea yang mempunyai pertumbuhan paling cepat sampai umur 20 tahun dibandingkan jenis Shorea lainnya.

Rata-rata diameter batang 10 pohon induk terbaik mencapai $11,9 \mathrm{~mm}$ atau dengan riap sebesar 0,66 mm/bulan. Riap tersebut jauh lebih besar jika dibandingkan dengan hasil penelitian 
Heriyanto dan Masano (1997) pada bibit $S$. leprosula di persemaian dengan hasil riap diameter berkisar antara 0,17-0,37 mm/bulan. Riap hasil penelitian ini juga masih lebih baik dari hasil penelitian Irwanto (2006) pada bibit $S$. leprosula di tempat terbuka dengan riap diameter $0,58 \mathrm{~mm} /$ bulan dan di dalam green house dengan riap diameter sebesar $0,46 \mathrm{~mm} / \mathrm{bulan}$. Apabila dibandingkan dengan jenis Shorea yang lain yaitu $S$. ovalis dengan perlakuan dosis pupuk NPK 15-15-15 sebanyak 0-1 g/bibit, riap diameter batang bibit $S$. leprosula jauh lebih baik. Dalam penelitian Herdiana dkk. (2008), riap diameter batang bibit $S$. ovalis berkisar antara 0,24-0,31 mm/bulan. Riap diameter batang bibit S. leprosula juga lebih baik dari S. selanica. Dari hasil penelitian Kosasih dan Heryati (2006), riap diameter batang bibit $S$. selanica dengan perlakuan beberapa jenis media berkisar antara 0,05 - 0,17 mm/bulan. Pertumbuhan tinggi dan diameter batang dalam penelitian ini lebih besar dibandingkan dengan hasil penelitian yang lain. Hal ini terjadi karena materi genetik yang digunakan dalam penelitian ini berasal dari materi yang terseleksi. Pada tingkat persemaian dengan media tanam yang terbatas, 10 pohon induk terbaik memiliki riap diameter sebesar 0,8 $\mathrm{cm} /$ tahun. Pada tingkat lapangan, riap diameter diharapkan lebih besar dari 1,67 cm/tahun, sebab Soekotjo (2009) menyampaikan bahwa sebagai spesies target dalam program SILIN jenis ini setelah ditanam di lapangan diharapkan dapat menghasilkan riap diameter sebesar 1,67 $\mathrm{cm} /$ tahun sehingga pada umur 30 tahun diameter batangnya dapat mencapai $50 \mathrm{~cm}$.

Dari Tabel 4 dapat diketahui pula bahwa bibit dari tujuh pohon induk dengan tinggi tertinggi juga sekaligus memiliki diameter terbesar dari 10 pohon induk terbaik. Dari data tersebut dapat diasumsikan bahwa antara pertumbuhan diameter batang dan tinggi bibit terdapat korelasi yang cukup tinggi. Hal ini sejalan dengan hasil penelitian Setiadi dkk. (2002) terhadap jenis Shorea selanica, yang menemukan bahwa pertumbuhan tinggi dan diameter batang berkorelasi positif.

Rata-rata jumlah percabangan terbanyak dari 10 pohon induk terbaik berkisar antara 7,3-8,7 cabang atau dengan rata-rata 7,8 cabang. Dalam pengembangan kebun pangkas $S$. leprosula, jumlah percabangan yang banyak diharapkan dapat memproduksi tunas othotroph yang banyak juga sebab menurut Leppe dan Smits (1988), cabang (tunas plagiotroph) S. leprosula dapat mengalami reiterasi proleptis yang akan menghasilkan tunas orthotroph. Lebih lanjut disampaikan bahwa stek yang dapat diambil pada reiterasi proleptis lebih banyak dibandingkan dari reiterasi syleptis. Untuk reiterasi proleptis, pada pengambilan stek tahap keempat dapat dihasilkan 14 stek sedang pada reiterasi syleptis hanya dapat dihasilkan 8 stek. Tabel 4 menunjukkan bahwa dari 10 pohon induk terbaik terdapat 3 pohon induk yang memiliki jumlah percabangan dan sekaligus memiliki tinggi dan diameter batang besar, yaitu pohon induk 1, 3 dan 6.

\section{KESIMPULAN}

Populasi S. leprosula Kenangan, Kalimantan Timur menghasilkan tinggi bibit, diameter batang dan jumlah percabangan terbesar, yaitu berturut-turut 132,3 cm, 10,6 mm dan 7,2 buah. 
Sepuluh pohon induk terbaik dalam karakter tinggi bibit adalah pohon induk nomor 7, 3, 4, $6,18,27,10,12,1$ dan 13 berturut-turut sebesar $173,3 \mathrm{~cm} ; 166,1 \mathrm{~cm} ; 165,8 \mathrm{~cm} ; 160,8 \mathrm{~cm} ; 150,0$ cm, 142,1 cm; 141,6 cm; 140,5 cm, 137,7 cm dan $133,4 \mathrm{~cm}$. Dan sepuluh pohon induk terbaik dalam karakter diameter batang adalah pohon induk nomor 7, 4, 6, 18, 3, 10, 17, 15, 19 dan 1 berturut-turut sebesar 13,63 mm; 13,00 mm; $12,93 \mathrm{~mm} ; 12,42 \mathrm{~mm} ; 12,35 \mathrm{~mm} ; 11,11 \mathrm{~mm}$; $11,03 \mathrm{~mm} ; 10,96 \mathrm{~mm} ; 10,78 \mathrm{~mm}$ dan $10,63 \mathrm{~mm}$, serta sepuluh pohon induk terbanyak dalam karakter jumlah percabangan adalah pohon induk nomor 3, 16, 12, 6, 9, 19, 2, 1, 17 dan 11 berturut-turut sebanyak 8,7 cabang; 8,5 cabang; 8,1 cabang; 8,0 cabang; 7,9 cabang; 7,5 cabang; 7,4 cabang; 7,3 cabang; 7,3 cabang dan 7,3 cabang.

\section{DAFTAR PUSTAKA}

Aminah, H., J.Mc.P. Dick, and J. Grace. 1997. Rooting of Shorea leprosula Stem Cutting Decrease with Increasing Leaf Area. Forest Ecology and Management 91: 247 - 254.

Appanah, S. dan G. Weinland. 1993. Planting Quality Timber Trees in Peninsula Malaysia. Forest Research Institute Malaysia Kepong Malayan Forest Record No. 38.

Ashton, P.M.S., Givinish, T.J., and Appanah, S. 1998. Staggered Flowering in

Dipterocarpaceae: New insights into floral induction and the evolution of mast flowering in the seasional tropic. American Naturalist $132: 44$ - 60 .

Danu, Siregar, I.Z., Cahyo, W. dan Atok, S. 2010. Pengaruh Umur Sumber Bahan Stek terhadap Keberhasilan Stek Pucuk Meranti Tembaga (Shorea leprosula Miq.). Jurnal Penelitian Hutan Tanaman Vol.7 No.3, Juli 2010: 131 - 139.

Hartati, D., Rimbawanto, A., Taryono, Sulistyaningsih, E. dan Widyatmoko, AYPBC. 2007. Pendugaan Keragaman Genetik di dalam dan Antar Provenan Pulai (Alstonia scholaris (L.) Br.) Menggunakan Penanda RAPD. Jurnal Pemuliaan Tanamann Hutan Vol. 1 No. 2. pp : 89 - 98.

Herdiana, H., Lukman, A.H. dan Mulyadi, K. 2008. Pengaruh Dosis dan Frekuensi Aplikasi Pemupukan NPK Terhadap Pertumbuhan Bibit Shorea ovalis Korth. (Blume) Asal Anakan Alam di Persemaian. Jurnal Penelitian Hutan dan Konservasi Alam Vol. V Nomor 3 Tahun 2008. Pusat Penelitian dan Pengembangan Hutan dan Konservasi Alam, Bogor.

Heriyanto, N.M., dan Masano. 1997. Pengaruh Media Serbuk Gergaji Terhadap Pertumbuhan Semai Shorea selanica Bl. dan Shorea leprosula Miq. Buletin Penelitian Hutan No. 607/1997. Pusat Penelitian dan Pengembangan Hutan dan Konservasi Alam, Bogor.

Hodgson, L.M. 1976. Some Aspects of Flowering and Reproductive Behaviour in Eucalyptus grandis (Hill) Maiden at J.D.M. Keet Forest Researh Station. 2. The Fruit, Seed, Seedlings, Self Fertility, Selfing and Inbreeding Effects. South African Forestry Journal $98: 32$ - 43 .

IFSP. 2002. Informasi Singkat Benih Shorea leprosula Miq. Direktorat Perbenihan 
Tanaman Hutan kerjasama dengan Indonesia Forest Seed Project (IFSP) T. H. R. Ir. H. Juanda, Dago Pakar . Bandung

Irwanto. 2006. Pengaruh Perbedaan Naungan Terhadap Pertumbuhan Semai Shorea spp. di Persemaian. Sekolah Pascasarjana UGM Jurusan Ilmu-Ilmu Pertanian.

Kosasih, A. S., dan Heryati, Y. 2006. Pengaruh Medium Sapih Terhadap Pertumbuhan Bibit Shorea selanica Bl. di Persemaian. Jurnal Penelitian Hutan dan Konservasi Alam Vol. III Nomor 2 Tahun 2006. Pusat Penelitian dan Pengembangan Hutan dan Konservasi Alam, Bogor.

Krishnapillay and Tompsett, P.B. 1998. Seed Handling. A Review of Dipterocarps : Taxonomy, Ecology, and Silvyculture. 73-88p. CIFOR. Bogor.

Leppe, D. dan Smits, W.T.M. 1988. Metoda Pembuatan dan Pemeliharaan Kebun Pangkas Dipterocarpaceae. Balai Penelitian dan Pengembangan Kehutanan Samarinda.

Lestyaningsih, I., Na'iem, M. dan Winarni, W.W. 2005. Variasi Isozim Meranti Merah (Shorea leprosula Miq.) dari Sumatera pada Tegakan Konservasi Ex-situ. Seminara Nasional Peningkatan Produktivitas Hutan. International Tropical Timber Organization dan Fakutas Kehutanan Universitas Gadjah Mada.

Na'iem, M., Raharjo, P. dan Wardana, E.K. 2005.

Evaluasi Awal Uji Keturunan Shorea leprosula di PT. ITCIKU, Kalimantan Timur. Seminara Nasional Peningkatan Produktivitas Hutan. International Tropical
Timber Organization dan Fakutas Kehutanan Universitas Gadjah Mada.

Cao, C.P., Finkeldey, R., Siregar, I.Z., Siregar, U.J., and Gailing, O. 2006. Genetic Diversity Within and Among Population of Shorea leprosula Miq. And Shorea parvifolia Dyer (Dipterocarpaceae) in Indonesia Detected by AFLPs. Tree Genetis \& Genomes Volume 2, Number 4, 225 - 239

Prihatini, I., Rimbawanto, A., Isoda K. 2001. Population genetic study of Shorea leprosula using RAPDs (Random Amplied Polymorphic DNAs). In : Thielges, B.A., Sastrapraja, S.D., and Rimbawanto, A. (Eds):In-situ and ex-situ conservation tropical trees. Proceeding International Seminar. Faculty of Forestry, Gadjah Mada University, Yogyakarta, 505-510.

Rimbawanto, A., and Isoda, K. 2001. Genetic structure of Shorea leprosula in a single population revealed by microsatellite markers. In : Thielges, B.A., Sastrapraja, S.D., and Rimbawanto, A. (Eds):In-situ and ex-situ conservation tropical trees. Proceeding International Seminar. Faculty of Forestry, Gadjah Mada University, Yogyakarta, 333-340.

Rimbawanto, A. dan Suharyanto. 2005. Keragaman Genetik Populasi Shorea leprosula Miq. dan Implikasinya untuk Program Konservasi Genetik. Seminar Nasional Peningkatan Produktivitas Hutan. Fakultas Kehutanan Universitas Gadjah Mada, Yogyakarta.

Rudjiman dan Adriyanti, D.T. 2002. Identification Manual of Shorea spp. ITTO 
Project PD 16/96 Rev. 4. Faculty of Forestry Gadjah Mada University, Yogyakarta.

Sagala, P. 1994. Mengelola Lahan Kehutanan Indonesia. Yayasan Obor Indonesia. Jakarta.

Sasaki, S. 1980. Storage and Germination of Dipterocarps Seeds. Forester 46(2) : 175 185.

Setiadi, D., Adinugraha, H.A., dan Suwandi. 2002. Pengaruh Dosis dan Frekuensi Pemupukan SNN (Super Natural Nutrition) Terhadap Pertumbuhan Semai Meranti Merah (Shorea selanica) di Persemaian. Buletin Penelitian Pemuliaan Pohon. Vol. 6 No. 1, 2002.

Siregar, U.J. 2001. Genetical studies for conservation of tropical timber species in Indonesia. In : Thielges, B.A., Sastrapraja, S.D., and Rimbawanto, A. (Eds): In-situ and ex-situ conservation tropical trees. Proceeding International Seminar. Faculty of Forestry, Gadjah Mada University, Yogyakarta, 207-212.

Soekotjo. 2009. Teknik Silvikultur Intensif (SILIN). Gadjah Mada University Press.

Soeseno, O.H. 2001. Current status of tree improvement in Indonesia. In Thielges, B.A., Sastrapraja, S.D., and Rimbawanto, A. (Eds):In-situ and ex-situ conservation tropical trees. Faculty of Forestry, Gadjah Mada University, Yogyakarta, 231-261.

Sudarmonowati, E., Hartati, N.S., Narendra, B.H., Basyuni, M., Siregar, U.J., Iriantono, D. 2001. Genetic markers for assessing genetic diversity and improvement of several tropical forest tree species to support conservation program. In : Thielges, B.A.,
Sastrapraja, S.D., and Rimbawanto, A. (Eds):In-situ and ex-situ conservation tropical trees. Proceeding International Seminar. Faculty of Forestry, Gadjah Mada University, Yogyakarta, 357-370.

Steel, R.G.D. dan Torrie, J.H. 1981. Principles and Procedures of Statistics : A Biometrical Approach. Second Edition. Mc Graw-Hill Book Company. Singapore.

Wyk, V.G. 1981. Inbreeding Effects in Eucalyptus grandis in Relation to Degree of Relatedness. South African Forestry Journal $116: 60-63$.

Yasman, I., and Natadiwirya, M. 2001. Dipterocarps plantation: the strategy and the approach of PT Inhutani I. In Thielges, B.A., Sastrapraja, S.D., and Rimbawanto, A. (Eds):In-situ and ex-situ conservation tropical trees. Faculty of Forestry, Gadjah Mada University, Yogyakarta, 407-412.

Zobel, B.J dan Talbert, J.T. 1984. Applied Forest Tree Improvement. John Wiley \& Sons Inc. Canada. 
Lampiran (Appendix) 1. Hasil analisis uji DMRT tinggi bibit, diameter batang dan jumlah percabangan bibit $S$. leprosula umur 18 bulan (Result of DMRT test on height, diameter, and number of branches of 18 months S. leprosula seedling)

\begin{tabular}{|c|c|c|c|c|c|c|}
\hline \multirow[b]{2}{*}{ No. } & \multicolumn{2}{|c|}{$\begin{array}{c}\text { Tinggi Bibit } \\
\text { (Seedlings height) }\end{array}$} & \multicolumn{2}{|c|}{$\begin{array}{c}\text { Diameter Batang } \\
\text { (Stem diameter) }\end{array}$} & \multicolumn{2}{|c|}{$\begin{array}{l}\text { Jumlah Percabangan } \\
\text { (Number of branches) }\end{array}$} \\
\hline & $\begin{array}{c}\text { Pohon } \\
\text { Induk } \\
\text { (Parent trees) }\end{array}$ & $\begin{array}{c}\text { Rata-rata } \\
\text { Tinggi (cm) } \\
\text { (Average of } \\
\text { height) }\end{array}$ & $\begin{array}{c}\text { Pohon } \\
\text { Induk } \\
\text { (Parent trees) }\end{array}$ & $\begin{array}{c}\text { Rata-rata } \\
\text { Diameter }(\mathbf{m m}) \\
\text { (Average of } \\
\text { diameter) }\end{array}$ & $\begin{array}{c}\text { Pohon } \\
\text { Induk } \\
\text { (Parent trees) }\end{array}$ & $\begin{array}{c}\text { Rata-rata } \\
\text { Percabangan } \\
\text { (Average of } \\
\text { branches) }\end{array}$ \\
\hline 1. & 7 & $173,3 \mathrm{a}$ & 7 & $13,63 \mathrm{a}$ & 3 & $8,7 \mathrm{a}$ \\
\hline 2. & 3 & $166,1 \mathrm{ab}$ & 4 & $13,00 \mathrm{a}$ & 16 & $8,5 \mathrm{ab}$ \\
\hline 3. & 4 & $165,8 \mathrm{ab}$ & 6 & $12,93 \mathrm{a}$ & 12 & $8,1 \mathrm{abc}$ \\
\hline 4. & 6 & $160,8 \mathrm{abc}$ & 18 & $12,42 \mathrm{ab}$ & 6 & $8,0 \mathrm{abc}$ \\
\hline 5. & 18 & $150,0 \mathrm{bcd}$ & 3 & $12,35 \mathrm{ab}$ & 9 & 7,9 abcd \\
\hline 6. & 27 & 142,1 cde & 10 & $11,11 \mathrm{bc}$ & 19 & 7,5 abcde \\
\hline 7. & 10 & 141,6 cde & 17 & $11,03 \mathrm{bc}$ & 2 & 7,4 abcde \\
\hline 8. & 12 & 140,5 cde & 15 & $10,96 \mathrm{bc}$ & 1 & 7,3 abcde \\
\hline 9. & 1 & 137,7 cdef & 19 & $10,78 \mathrm{bcd}$ & 17 & 7,3 abcde \\
\hline 10. & 13 & 133,4 defg & 1 & $10,63 \mathrm{cde}$ & 11 & 7,3 abcde \\
\hline 11. & 17 & 132,6 defgh & 35 & $10,36 \mathrm{cdef}$ & 8 & 7,1 abcdef \\
\hline 12. & 20 & 128,7 defghi & 12 & $10,36 \mathrm{cdef}$ & 13 & 7,0 abcdefg \\
\hline 13. & 15 & 126,0 defghij & 13 & 10,11 cdefg & 27 & 6,8 bcdefgh \\
\hline 14. & 16 & 124,6 efghij & 16 & 10,06 cdefg & 10 & 6,7 bcdefgh \\
\hline 15. & 19 & 124,5 efghij & 20 & 9,92 cdefgh & 14 & 6,7 bcdefgh \\
\hline 16. & 30 & 124,5 efghij & 27 & 9,79 cdefghi & 7 & 6,6 cdefgh \\
\hline 17. & 8 & 122,2 efghij & 24 & 9,39 cdefghij & 4 & 6,5 cdefghi \\
\hline 18. & 14 & 117,9 efghijk & 2 & 9,14 defghij & 15 & 6,5 cdefghi \\
\hline 19. & 22 & 114,5 fghijkl & 8 & 9,13 defghij & 18 & 6,3 cdefghij \\
\hline 20. & 11 & 113,5 fghijkl & 9 & 8,95 efghij & 34 & 6,3 cdefghij \\
\hline 21. & 24 & 113,2 fghijkl & 14 & 8,92 efghij & 30 & 6,2 cdefghij \\
\hline 22. & 29 & 112,4 ghijkl & 28 & 8,86 fghij & 25 & 6,0 defghijk \\
\hline 23. & 35 & 111,5 ghijkl & 30 & 8,79 fghijk & 37 & 5,9 efghijkl \\
\hline 24. & 9 & 111,2 ghijkl & 40 & 8,73 fghijk & 23 & 5,9 efghijkl \\
\hline 25. & 23 & 111,2 ghijkl & 11 & 8,73 fghijk & 40 & 5,7 efghijklm \\
\hline 26. & 34 & 108,2 ghijklm & 36 & 8,66 fghijk & 20 & 5,3 fghijklm \\
\hline 27. & 25 & 107,8 hijklm & 25 & 8,58 fghijkl & 26 & 5,3 fghijklm \\
\hline 28. & 36 & $105,8 \mathrm{ijklmn}$ & 21 & 8,51 ghijkl & 28 & 5,2 fghijklm \\
\hline 29. & 40 & 104,4 ijklmn & 23 & 8,38 ghijkl & 24 & 5,1 ghijklm \\
\hline 30. & 2 & $104,3 \mathrm{ijklmn}$ & 22 & 8,33 ghijkl & 29 & $5,0 \mathrm{ijklm}$ \\
\hline 31. & 26 & 103,5 ijklmn & 34 & 8,22 hijklm & 36 & $5,0 \mathrm{ijklm}$ \\
\hline 32. & 21 & $103,2 \mathrm{ijklmn}$ & 29 & $8,11 \mathrm{ijklm}$ & 22 & 4,9 ijklmn \\
\hline 33. & 28 & $103,0 \mathrm{jklmn}$ & 37 & 8,05 ijklm & 21 & 4,6 ijklmno \\
\hline 34. & 37 & $101,5 \mathrm{jklmn}$ & 26 & $7,70 \mathrm{jklmn}$ & 33 & 4,6 ijklmno \\
\hline 35. & 32 & $94,5 \mathrm{klmn}$ & 38 & 7,58 jklmn & 5 & 4,6 ijklmno \\
\hline 36. & 33 & 89,3 lmno & 42 & $7,05 \mathrm{klmn}$ & 32 & 4,4 jklmno \\
\hline 37. & 42 & 84,8 mnop & 32 & $7,03 \mathrm{klmn}$ & 35 & 4,3 klmno \\
\hline 38. & 31 & 82,4 nop & 5 & $6,86 \mathrm{lmn}$ & 38 & 4,1 lmnop \\
\hline 39. & 38 & 70,0 op & 33 & $6,51 \mathrm{mno}$ & 31 & 4,0 mnop \\
\hline 40. & 5 & 68,3 op & 31 & 6,35 no & 39 & 3,1 nop \\
\hline 41. & 39 & $62,5 \mathrm{p}$ & 39 & 6,30 no & 41 & 3,0 op \\
\hline 42. & 41 & $39,0 \mathrm{q}$ & 41 & 5,03 o & 42 & $2,5 \mathrm{p}$ \\
\hline
\end{tabular}

Keterangan (Remarks) : Pohon Induk 1 - 19 : populasi Kenangan, Kalimantan Timur 